\title{
Long-Term Care in New York - A 2021 Survey of Registered Voters 50 Years and Older: Annotated Questionnaire
}

March 2022

\section{Screening Questions}

S1. Our study is interested in the opinions of people in certain age groups. Could you please tell me your age as of your last birthday? [IN YEARS] [RECORD ACTUAL AGE AND USE THE AGE GROUPS BELOW TO KEEP TRACK OF HOW MANY RESPONDENTS WE ARE GETTING IN EACH GROUP] S2. [IF REFUSED IN S1:] I understand. Some people are not comfortable giving their age, but would you let me know which of the following age ranges you fall into?

\begin{tabular}{|l|c|}
\hline & Total \\
\hline Weighted $n$ & 1201 \\
\hline 40 to 49 & $0.0 \%$ \\
\hline 50 to 54 & $16.0 \%$ \\
\hline 55 to 64 & $33.9 \%$ \\
\hline $65+$ & $50.2 \%$ \\
\hline Refused [THANK \& TERMINATE] & $0.0 \%$ \\
\hline
\end{tabular}

S3. To ensure it is recorded accurately, could you please state your gender? [CODE TO LIST BELOW]

\begin{tabular}{|l|c|}
\hline & Total \\
\hline Weighted $n$ & 1201 \\
\hline Man & $44.4 \%$ \\
\hline Woman & $55.4 \%$ \\
\hline Non-Binary & $0.0 \%$ \\
\hline Another gender identity & $0.0 \%$ \\
\hline Not sure [DO NOT READ] & $0.0 \%$ \\
\hline Refused [DO NOT READ] & $0.2 \%$ \\
\hline
\end{tabular}

S4. Are you registered to vote in New York?

\begin{tabular}{|l|c|}
\hline & Total \\
\hline Weighted $n$ & 1201 \\
\hline Yes & $100.0 \%$ \\
\hline No [THANK \& TERMINATE] & $0.0 \%$ \\
\hline
\end{tabular}


S5. Are you of Hispanic, Spanish, or Latino origin or descent?

\begin{tabular}{|l|c|}
\hline & Total \\
\hline Weighted $n$ & 1201 \\
\hline Yes & $8.6 \%$ \\
\hline No & $90.1 \%$ \\
\hline Not sure [DO NOT READ] & $0.9 \%$ \\
\hline Refused [DO NOT READ] & $0.4 \%$ \\
\hline
\end{tabular}

S6. What is your race? Are you ...? [INSERT AND READ EACH ANSWER CATEGORY AND ACCEPT MULTIPLE RESPONSES]

\begin{tabular}{|l|c|}
\hline & Total \\
\hline Weighted $n$ & 1201 \\
\hline White or Caucasian & $78.6 \%$ \\
\hline Black or African American & $8.4 \%$ \\
\hline Native American or Alaskan Native & $1.8 \%$ \\
\hline Asian & $3.5 \%$ \\
\hline Native Hawaiian or other Pacific Islander & $0.3 \%$ \\
\hline Or are you some other race? & $6.5 \%$ \\
\hline Not sure [DO NOT READ] & $1.2 \%$ \\
\hline Refused [DO NOT READ] & $1.8 \%$ \\
\hline
\end{tabular}

\section{Main Questionnaire}

\section{Family Caregiver}

Q1. A family caregiver is someone who provides UNPAID care for an adult loved one who is ill, frail, elderly, or has a physical, mental, or emotional disability. This UNPAID care may include assisting with personal needs like bathing and dressing, household chores, meals, shopping, transportation, or managing finances or medical care. Are you now or have you ever been a family caregiver who provided UNPAID care to an adult loved one? [INTERVIEWER NOTE: IF THE RESPONDENTS ASKS IF THE PERSON THEY PROVIDE OR HAVE PROVIDED CARE TO HAD TO LIVE WITH THEM, THE INTERVIEWER SHOULD SAY ... "THIIS PERSON DID NOT HAVE TO LIVE WITH YOU..']

\begin{tabular}{|l|c|}
\hline & Total \\
\hline Weighted $n$ & 1201 \\
\hline Yes, I am currently providing unpaid care to an adult loved one & $11.2 \%$ \\
\hline Yes, I have been an unpaid family caregiver in the past & $30.7 \%$ \\
\hline No, I have never been an unpaid caregiver & $57.8 \%$ \\
\hline Not sure [DO NOT READ] & $0.2 \%$ \\
\hline Refused [DO NOT READ] & $0.1 \%$ \\
\hline
\end{tabular}


Q2. IF CURRENT OR FORMER CAREGIVER, ASK Q2-Q6. Have you ever been employed either full- or part-time while providing care to your adult loved one?

\begin{tabular}{|l|c|c|c|c|}
\hline Current \& Former Caregivers & Total & AA/B & H/L & A/PI \\
\hline Weighted $n$ & 504 & 92 & 82 & 73 \\
\hline Yes & $68.4 \%$ & $71.8 \%$ & $53.9 \%$ & $65.8 \%$ \\
\hline No & $31.6 \%$ & $28.2 \%$ & $46.1 \%$ & $34.2 \%$ \\
\hline Not sure [DO NOT READ] & $0.0 \%$ & $0.0 \%$ & $0.0 \%$ & $0.0 \%$ \\
\hline Refused [DO NOT READ] & $0.0 \%$ & $0.0 \%$ & $0.0 \%$ & $0.0 \%$ \\
\hline
\end{tabular}

Questions 3-5 may be released at a later date.

Q6. As a caregiver do [DID FOR FORMER CAREGIVERS] you ever ...? [INSERT, READ AND RANDOMIZE ITEMS A-C] [RECORD A RESPONSE FOR EACH ITEM]

\begin{tabular}{|l|c|}
\hline Current \& Former Caregivers & Total \\
\hline Weighted $n$ & 504 \\
\hline a. Feel stressed emotionally due to your caregiving responsibilities & $73.4 \%$ \\
\hline b. Feel strained financially due to your caregiving responsibilities & $37.2 \%$ \\
\hline Weighted $n$ (working caregivers) & 344 \\
\hline $\begin{array}{l}\text { c. Feel stressed in balancing your job and family responsibilities } \\
\text { [SKIP IF ANSWERED NO/NOT SURE/REFUSED TO Q2] }\end{array}$ & $74.9 \%$ \\
\hline
\end{tabular}

Question 7 may be released at a later date.

Q8. Do you believe that the New York state government offers enough support for unpaid family caregivers?

\begin{tabular}{|l|c|}
\hline & Total \\
\hline Weighted $n$ & 1201 \\
\hline Yes & $16.4 \%$ \\
\hline No & $51.5 \%$ \\
\hline Not sure [DO NOT READ] & $32.1 \%$ \\
\hline Refused [DO NOT READ] & $0.0 \%$ \\
\hline
\end{tabular}

Questions 9-11 may be released at a later date.

\section{$\underline{\text { Tax Credit }}$}

Q12. Do you support or oppose providing a limited state income tax credit to family caregivers who incur expenses for the care and support of a family member living in New York? Q13. Is that strongly or somewhat?

\begin{tabular}{|l|c|}
\hline & Total \\
\hline Weighted $n$ & 1201 \\
\hline Strongly support & $63.6 \%$ \\
\hline Somewhat support & $21.2 \%$ \\
\hline Neither support/oppose/not sure [DO NOT READ] & $6.4 \%$ \\
\hline
\end{tabular}




\begin{tabular}{|l|c|}
\hline Somewhat oppose & $3.2 \%$ \\
\hline Strongly oppose & $5.6 \%$ \\
\hline Refused [DO NOT READ] & $0.0 \%$ \\
\hline SUPPORT & $84.8 \%$ \\
\hline OPPOSE & $8.8 \%$ \\
\hline
\end{tabular}


Long-Term Care

Long-term care assists older Americans who have chronic or acute conditions, disabilities, or frailties with the basic tasks of daily living that they can no longer handle on their own. This includes things like bathing and dressing, preparing meals, helping with medication and nursing tasks like wound care, paying bills, housekeeping, and helping with trips to the doctor or store. Long-term care can be provided at home or in a facility, like a nursing home.

Q14. If you or a loved one needed long-term care, where would you prefer to receive that help? [INSERT, READ AND RANDOMIZE ITEMS A-C. ACCEPT ONLY ONE ANSWER]

\begin{tabular}{|l|c|}
\hline & Total \\
\hline Weighted $n$ & 1201 \\
\hline a. At home with caregiver assistance & $87.0 \%$ \\
\hline b. In a nursing home & $2.3 \%$ \\
\hline c. In an assisted living facility or group home & $6.7 \%$ \\
\hline Something else [DO NOT READ] & $1.1 \%$ \\
\hline Not sure [DO NOT READ] & $2.9 \%$ \\
\hline Refused [DO NOT READ] & $0.0 \%$ \\
\hline
\end{tabular}

Q15. If you or a loved one needed long-term care, how important would it be to have services that would help you or your loved one stay at home for as long as possible? Is it ... [INSERT AND READ RESPONSE OPTIONS IN ORDER]?

\begin{tabular}{|l|c|}
\hline & Total \\
\hline Weighted $n$ & 1201 \\
\hline Extremely important & $61.2 \%$ \\
\hline Very important & $27.0 \%$ \\
\hline Somewhat important & $8.1 \%$ \\
\hline Not very important & $0.9 \%$ \\
\hline Not at all important & $0.7 \%$ \\
\hline Not sure [DO NOT READ] & $1.7 \%$ \\
\hline Refused [DO NOT READ] & $0.3 \%$ \\
\hline
\end{tabular}

Q16. If you or a loved one needed long-term care, how important is it for you or your loved one to be able to choose where those services are provided? Is it ... [INSERT AND READ RESPONSE OPTIONS IN ORDER]?

\begin{tabular}{|l|c|}
\hline & Total \\
\hline Weighted $n$ & 1201 \\
\hline Extremely important & $63.5 \%$ \\
\hline Very important & $29.8 \%$ \\
\hline Somewhat important & $4.9 \%$ \\
\hline Not very important & $0.5 \%$ \\
\hline Not at all important & $0.5 \%$ \\
\hline Not sure [DO NOT READ] & $0.6 \%$ \\
\hline Refused [DO NOT READ] & $0.2 \%$ \\
\hline
\end{tabular}


Q17. If you or a loved one needed to receive care in a nursing home, how concerned would you be about ... [INSERT, READ AND RANDOMIZE ITEMS A-E]? Would you be ... [INSERT AND READ RESPONSE OPTIONS IN ORDER]

a. The cost of care?

\begin{tabular}{|l|c|}
\hline & Total \\
\hline Weighted $n$ & 1201 \\
\hline Extremely concerned & $57.5 \%$ \\
\hline Very concerned & $27.7 \%$ \\
\hline Somewhat concerned & $10.5 \%$ \\
\hline Not very concerned & $1.2 \%$ \\
\hline Not at all concerned & $1.6 \%$ \\
\hline Not sure [DO NOT READ] & $1.4 \%$ \\
\hline Refused [DO NOT READ] & $0.1 \%$ \\
\hline
\end{tabular}

b. Exposure to COVID-19 or its variants or other infections?

\begin{tabular}{|l|c|}
\hline & Total \\
\hline Weighted $n$ & 1201 \\
\hline Extremely concerned & $51.5 \%$ \\
\hline Very concerned & $26.2 \%$ \\
\hline Somewhat concerned & $12.0 \%$ \\
\hline Not very concerned & $5.5 \%$ \\
\hline Not at all concerned & $3.4 \%$ \\
\hline Not sure [DO NOT READ] & $1.1 \%$ \\
\hline Refused [DO NOT READ] & $0.3 \%$ \\
\hline
\end{tabular}

c. Being isolated and alone?

\begin{tabular}{|l|c|}
\hline & Total \\
\hline Weighted $n$ & 1201 \\
\hline Extremely concerned & $54.3 \%$ \\
\hline Very concerned & $31.7 \%$ \\
\hline Somewhat concerned & $8.3 \%$ \\
\hline Not very concerned & $2.2 \%$ \\
\hline Not at all concerned & $2.2 \%$ \\
\hline Not sure [DO NOT READ] & $1.0 \%$ \\
\hline Refused [DO NOT READ] & $0.4 \%$ \\
\hline
\end{tabular}

d. Not being able to have visitors?

\begin{tabular}{|l|c|}
\hline & Total \\
\hline Weighted $n$ & 1201 \\
\hline Extremely concerned & $57.2 \%$ \\
\hline Very concerned & $28.7 \%$ \\
\hline Somewhat concerned & $9.4 \%$ \\
\hline Not very concerned & $2.1 \%$ \\
\hline Not at all concerned & $1.3 \%$ \\
\hline Not sure [DO NOT READ] & $1.3 \%$ \\
\hline Refused [DO NOT READ] & $0.0 \%$ \\
\hline
\end{tabular}


e. The nursing home not having enough staff to provide care?

\begin{tabular}{|l|c|}
\hline & Total \\
\hline Weighted $n$ & 1201 \\
\hline Extremely concerned & $65.5 \%$ \\
\hline Very concerned & $28.1 \%$ \\
\hline Somewhat concerned & $4.1 \%$ \\
\hline Not very concerned & $0.3 \%$ \\
\hline Not at all concerned & $1.0 \%$ \\
\hline Not sure [DO NOT READ] & $0.9 \%$ \\
\hline Refused [DO NOT READ] & $0.2 \%$ \\
\hline
\end{tabular}

f. The quality of care you or your loved one would receive?

\begin{tabular}{|l|c|}
\hline & Total \\
\hline Weighted $n$ & 1201 \\
\hline Extremely concerned & $67.7 \%$ \\
\hline Very concerned & $27.8 \%$ \\
\hline Somewhat concerned & $2.5 \%$ \\
\hline Not very concerned & $0.8 \%$ \\
\hline Not at all concerned & $0.5 \%$ \\
\hline Not sure [DO NOT READ] & $0.8 \%$ \\
\hline Refused [DO NOT READ] & $0.0 \%$ \\
\hline
\end{tabular}

\section{Transparency}

Q18. Currently, safety inspections of nursing homes and other long-term care facilities do not occur on a regular, ongoing basis, such as monthly. Do you support or oppose increasing the frequency of these inspections to at least once each year? Q19. Is that strongly or somewhat?

\begin{tabular}{|l|c|}
\hline & Total \\
\hline Weighted $n$ & 1201 \\
\hline Strongly support & $86.1 \%$ \\
\hline Somewhat support & $7.5 \%$ \\
\hline Neither support/oppose/not sure [DO NOT READ] & $2.7 \%$ \\
\hline Somewhat oppose & $1.5 \%$ \\
\hline Strongly oppose & $2.2 \%$ \\
\hline Refused [DO NOT READ] & $0.0 \%$ \\
\hline SUPPORT & $93.6 \%$ \\
\hline OPPOSE & $2.7 \%$ \\
\hline
\end{tabular}

Question 20 may be released at a later date. 
$\underline{\text { Staffing }}$

Q21. Many nursing homes and other long-term care facilities are currently experiencing a shortage of staff and have difficulties in hiring new staff. Do you support or oppose increasing government funding to nursing homes and other long-term care facilities to improve pay and benefits to help attract and maintain staff? Q22. Is that strongly or somewhat?

\begin{tabular}{|l|c|}
\hline \multicolumn{1}{|c|}{} & Total \\
\hline Weighted $n$ & 1201 \\
\hline Strongly support & $67.9 \%$ \\
\hline Somewhat support & $17.1 \%$ \\
\hline Neither support/oppose/not sure [DO NOT READ] & $5.3 \%$ \\
\hline Somewhat oppose & $3.1 \%$ \\
\hline Strongly oppose & $6.6 \%$ \\
\hline Refused [DO NOT READ] & $0.1 \%$ \\
\hline SUPPORT & $85.0 \%$ \\
\hline OPPOSE & $9.7 \%$ \\
\hline
\end{tabular}

Questions 23-24 may be released at a later date.

\section{$\underline{\text { Home Care }}$}

Q25. Do you support or oppose increasing community and state services to help seniors live independently at home longer as they age? Q26. Is that strongly or somewhat?

\begin{tabular}{|l|c|}
\hline & Total \\
\hline Weighted $n$ & 1201 \\
\hline Strongly support & $81.5 \%$ \\
\hline Somewhat support & $12.1 \%$ \\
\hline Neither support/oppose/not sure [DO NOT READ] & $3.1 \%$ \\
\hline Somewhat oppose & $0.9 \%$ \\
\hline Strongly oppose & $2.4 \%$ \\
\hline Refused [DO NOT READ] & $0.0 \%$ \\
\hline SUPPORT & $93.6 \%$ \\
\hline OPPOSE & $3.3 \%$ \\
\hline
\end{tabular}


Q27. In the last year, about eleven thousand seniors have been on a waiting list to receive long-term care at home. Do you support or oppose increasing funding so more seniors can receive long-term care at home, instead of a nursing home? Q28. Is that strongly or somewhat?

\begin{tabular}{|l|c|}
\hline & Total \\
\hline Weighted $n$ & 1201 \\
\hline Strongly support & $80.6 \%$ \\
\hline Somewhat support & $12.0 \%$ \\
\hline Neither support/oppose/not sure [DO NOT READ] & $2.9 \%$ \\
\hline Somewhat oppose & $2.1 \%$ \\
\hline Strongly oppose & $2.3 \%$ \\
\hline Refused [DO NOT READ] & $0.2 \%$ \\
\hline SUPPORT & $92.6 \%$ \\
\hline OPPOSE & $4.4 \%$ \\
\hline
\end{tabular}

Questions 29-33 may be released at a later date.

\section{Demographic Questions}

The following questions are for classification purposes only and will be kept entirely confidential.

D1. What is your current marital status? Are you ...? [INSERT AND READ EACH ANSWER CATEGORY]

\begin{tabular}{|l|c|}
\hline & Total \\
\hline Weighted $n$ & 1201 \\
\hline Married & $55.0 \%$ \\
\hline Not married, but living with your partner or significant other & $4.4 \%$ \\
\hline Separated & $2.1 \%$ \\
\hline Divorced & $14.0 \%$ \\
\hline Widowed & $8.9 \%$ \\
\hline Or are you currently single and never married & $12.9 \%$ \\
\hline Not sure [DO NOT READ] & $0.6 \%$ \\
\hline Refused [DO NOT READ] & $2.1 \%$ \\
\hline
\end{tabular}


D2. [IF D1 = 1 ASK: "Are you or your spouse currently a member of A-A-R-P?" IF D1 = 2 ASK: "Are you or your partner currently a member of A-A-R-P?" OTHERWISE ASK "Are you currently a member of A-A-R-P?"]

\begin{tabular}{|l|c|}
\hline & Total \\
\hline Weighted $n$ & 1201 \\
\hline Yes & $35.0 \%$ \\
\hline No & $62.2 \%$ \\
\hline Not sure [DO NOT READ] & $2.1 \%$ \\
\hline Refused [DO NOT READ] & $0.7 \%$ \\
\hline
\end{tabular}

D3. Would you say your health in general is ...? [INSERT AND READ EACH ANSWER CATEGORY]

\begin{tabular}{|l|c|}
\hline & Total \\
\hline Weighted $n$ & 1201 \\
\hline Excellent & $19.0 \%$ \\
\hline Very good & $31.0 \%$ \\
\hline Good & $32.2 \%$ \\
\hline Fair & $13.0 \%$ \\
\hline Poor & $3.7 \%$ \\
\hline Not sure [DO NOT READ] & $0.6 \%$ \\
\hline Refused [DO NOT READ] & $0.5 \%$ \\
\hline
\end{tabular}

D4. Do you own or rent your primary residence?

\begin{tabular}{|l|c|}
\hline & Total \\
\hline Weighted $n$ & 1201 \\
\hline Own & $69.8 \%$ \\
\hline Rent & $25.2 \%$ \\
\hline Other living arrangement [DO NOT READ] & $2.4 \%$ \\
\hline Not sure [DO NOT READ] & $0.8 \%$ \\
\hline Refused [DO NOT READ] & $1.8 \%$ \\
\hline
\end{tabular}

D5. What type of home is your primary residence? Is it ...? [READ EACH ANSWER CATEGORY]

\begin{tabular}{|l|c|}
\hline & Total \\
\hline Weighted $n$ & 1201 \\
\hline Single family home & $67.6 \%$ \\
\hline Mobile home & $2.4 \%$ \\
\hline Town home or duplex & $3.2 \%$ \\
\hline Apartment & $17.3 \%$ \\
\hline Condominium or coop, or & $6.0 \%$ \\
\hline Something else [DO NOT READ] & $1.6 \%$ \\
\hline Not sure [DO NOT READ] & $0.6 \%$ \\
\hline Refused [DO NOT READ] & $1.3 \%$ \\
\hline
\end{tabular}


D6. What is the highest level of education that you completed? Is it ...? [READ EACH ANSWER CATEGORY]

\begin{tabular}{|l|c|}
\hline & Total \\
\hline Weighted $n$ & 1201 \\
\hline 0 to $12^{\text {th }}$ grade, but with no diploma & $3.7 \%$ \\
\hline High school graduate or equivalent & $21.0 \%$ \\
\hline Post high school education, but with no degree & $10.8 \%$ \\
\hline 2 year degree & $16.2 \%$ \\
\hline 4 year degree & $20.8 \%$ \\
\hline Post graduate study, but with no degree & $5.8 \%$ \\
\hline Graduate or professional degree & $18.4 \%$ \\
\hline Not sure [DO NOT READ] & $1.1 \%$ \\
\hline Refused [DO NOT READ] & $2.2 \%$ \\
\hline
\end{tabular}

D7. Which of the following best describes your current employment status? Are you ...? [READ EACH ANSWER CATEGORY]

\begin{tabular}{|l|c|}
\hline & Total \\
\hline Weighted $n$ & 1201 \\
\hline Self-employed full-time & $6.8 \%$ \\
\hline Self-employed part-time & $4.2 \%$ \\
\hline Employed full-time & $26.1 \%$ \\
\hline Employed part-time & $8.4 \%$ \\
\hline Retired and not working at all & $45.2 \%$ \\
\hline Unemployed and looking for work & $2.3 \%$ \\
\hline Or are you not in the labor force for other reasons & $4.6 \%$ \\
\hline Not sure [DO NOT READ] & $0.9 \%$ \\
\hline Refused [DO NOT READ] & $1.6 \%$ \\
\hline
\end{tabular}

D8. Thinking about your state elections for New York Governor and State Legislators in the last 10 years, which of the following best describes your voting behavior? Would you say you vote ...? [INSERT AND READ EACH ANSWER CATEGORY]

\begin{tabular}{|l|c|}
\hline & Total \\
\hline Weighted $n$ & 1201 \\
\hline Always & $64.6 \%$ \\
\hline Most of the time & $22.1 \%$ \\
\hline About half of the time & $6.6 \%$ \\
\hline Seldom, or & $3.5 \%$ \\
\hline Never & $1.2 \%$ \\
\hline Not sure [DO NOT READ] & $1.1 \%$ \\
\hline Refused [DO NOT READ] & $0.9 \%$ \\
\hline
\end{tabular}


D9. Do you consider yourself to be a ...? [INSERT, READ AND RANDOMIZE ITEMS A-C, FOLLOW UP WITH D]

\begin{tabular}{|l|c|}
\hline & Total \\
\hline Weighted $n$ & 1201 \\
\hline a. Democrat & $40.9 \%$ \\
\hline b. Republican & $23.5 \%$ \\
\hline c. Independent & $20.7 \%$ \\
\hline d. Something else [DO NOT READ] & $9.3 \%$ \\
\hline Not sure [DO NOT READ] & $2.4 \%$ \\
\hline Refused [DO NOT READ] & $3.2 \%$ \\
\hline
\end{tabular}

D10. How would you characterize your political views? Would you say you are ...? [INSERT, READ AND RANDOMIZE ITEMS A-C]

\begin{tabular}{|l|c|}
\hline & Total \\
\hline Weighted $n$ & 1201 \\
\hline a. Conservative & $31.6 \%$ \\
\hline b. Moderate & $34.5 \%$ \\
\hline c. Liberal & $21.4 \%$ \\
\hline None of these [DO NOT READ] & $4.1 \%$ \\
\hline Not sure [DO NOT READ] & $4.8 \%$ \\
\hline Refused [DO NOT READ] & $3.6 \%$ \\
\hline
\end{tabular}

D11. We realize income is a private matter and so rather than ask you anything specific about your income, l'd like to ask you to please stop me when I get to the category that includes your household's income before taxes in 2020. Was it ...? [INSERT AND READ EACH ANSWER CATEGORY]

\begin{tabular}{|l|c|}
\hline & Total \\
\hline Weighted $n$ & 1201 \\
\hline Less than $\$ 10,000$ & $3.7 \%$ \\
\hline$\$ 10,000$ to less than $\$ 20,000$ & $7.6 \%$ \\
\hline$\$ 20,000$ to less than $\$ 30,000$ & $6.2 \%$ \\
\hline$\$ 30,000$ to less than $\$ 40,000$ & $8.2 \%$ \\
\hline$\$ 40,000$ to less than $\$ 50,000$ & $6.2 \%$ \\
\hline$\$ 50,000$ to less than $\$ 60,000$ & $6.9 \%$ \\
\hline$\$ 60,000$ to less than $\$ 75,000$ & $9.4 \%$ \\
\hline$\$ 75,000$ to less than $\$ 100,000$ & $10.8 \%$ \\
\hline$\$ 100,000$ to less than $\$ 125,000$ & $6.6 \%$ \\
\hline$\$ 125,000$ to less than $\$ 150,000$ & $4.6 \%$ \\
\hline$\$ 150,000$ to less than $\$ 200,000$ & $3.2 \%$ \\
\hline$\$ 200,000$ or more & $5.9 \%$ \\
\hline Not sure [DO NOT READ] & $4.9 \%$ \\
\hline Refused [DO NOT READ] & $15.7 \%$ \\
\hline
\end{tabular}


D12. Which of the following best describes the community where you live? [INSERT AND READ EACH RESPONSE OPTION IN ORDER]

\begin{tabular}{|l|c|}
\hline & Total \\
\hline Weighted $n$ & 1201 \\
\hline An urban area near a mix of offices, apartments and shops & $12.3 \%$ \\
\hline An urban area that is mostly residential & $18.9 \%$ \\
\hline A suburban area with a mix of offices, apartments and shops & $9.7 \%$ \\
\hline A suburban area that is mostly residential & $19.0 \%$ \\
\hline A small town, or & $16.4 \%$ \\
\hline A rural area & $17.9 \%$ \\
\hline Not sure [DO NOT READ] & $3.2 \%$ \\
\hline Refused [DO NOT READ] & $2.6 \%$ \\
\hline
\end{tabular}

D13. Does any disability, handicap, or chronic disease keep you from participating fully in work, school, household, or other activities?

\begin{tabular}{|l|c|}
\hline & Total \\
\hline Weighted $n$ & 1201 \\
\hline Yes & $22.2 \%$ \\
\hline No & $74.2 \%$ \\
\hline Not sure [DO NOT READ] & $1.6 \%$ \\
\hline Refused [DO NOT READ] & $2.0 \%$ \\
\hline
\end{tabular}

D14. Do you identify as L-G-B-T-Q? Is that yes, no, or do you prefer not to say?

\begin{tabular}{|l|c|}
\hline & Total \\
\hline Weighted $n$ & 1201 \\
\hline Yes & $2.6 \%$ \\
\hline No & $90.0 \%$ \\
\hline Prefer not to say & $1.6 \%$ \\
\hline Not sure [DO NOT READ] & $3.1 \%$ \\
\hline Refused [DO NOT READ] & $2.7 \%$ \\
\hline
\end{tabular}

Thank you. That is our last question for today/tonight. 
AARP New York commissioned a telephone survey among 1,201 registered voters age 50-plus in New York to learn their views on long-term care and related proposals being considered by the New York State Legislature. This main sample utilized an age-targeted landline and cell phone registered voter list obtained from Aristotle International. This study included an oversample of 200 registered voters who identify their race as African American or Black and 200 registered voters who identify their ethnicity as Hispanic or Latino. An additional oversample of 202 registered voters age 40-plus who identify their race as Asian or Pacific Islander was also conducted via a nonprobability methodology of opt-in online and live telephone interviews.

The main sample database consisted of 6,291,987 registered voters age 50-plus in the State of New York. There are approximately 880,639 residents of New York age 50-plus who are not registered to vote, and there are approximately 2,626,104 registered voters age 50-plus who did not have a phone number on file that were not included in the sampling of this study.

Quotas were used in this study based on age and gender and were filled based on responses to questions in the questionnaire. They were designed to yield a proportional representation of the New York age 50-plus registered voter population. Respondents were selected at random from the main sample list to be dialed. American Directions Research Group (ADRG) asked to speak with the registered voter listed on the file. If that person was unavailable, ADRG asked to speak with another member of the household aged 50-plus who was registered to vote in New York. The interviews averaged 17 minutes in length and were conducted in English and Spanish. The survey has a margin of sampling error of \pm 2.83 percent.

This annotation highlights results from 1,201 registered voters 50-plus and from 202 registered voters 40 -plus conducted from the opt-in panel. Voters were interviewed from November 16, 2021 to December 12, 2021. The data collection was performed by ADRG. The data is weighted by age, gender, race and ethnicity, and AARP membership status. Percentages reported are rounded. For more information about the methodology, contact Terri Guengerich, AARP Research, tguengerich@aarp.org, (202)434-6306. 